\title{
Evaluation of Physico-Mechanical Properties of Crushed Rock Aggregates: A Case Study from the Sub-Himalaya, Pakistan
}

\author{
Yasir SARFRAZ ${ }^{1}$, Muhammad BASHARAT, ${ }^{1}$ Muhammad Tayyib RIAZ ${ }^{1,2 *}$, \\ Muhammad Arshad KHAN ${ }^{3}$, Amir SHAHZAD ${ }^{1,2}$ and Khawaja Shoaib AHMED ${ }^{1}$
}

\author{
Authors' affiliations and addresses: \\ ${ }^{1}$ Institute of Geology, University of Azad Jammu \\ and Kashmir Muzaffarabad, Pakistan \\ e-mail: geologist.ajk@gmail.com \\ e-mail: basharatgeo@yahoo.com \\ e-mail: ksageologist@gmail.com \\ ${ }^{2}$ Department of Geology, University of Azad \\ Jammu and Kashmir, Neelum Campus, Pakistan \\ e-mail: tayyibriaz@yahoo.com \\ e-mail: amirshahzadgeo@gmail.com \\ ${ }^{3}$ Department of Earth Sciences, University of \\ Poonch, Rawalakot, Pakistan \\ e-mail: hod.geology@upr.edu.pk
}

\section{*Correspondence:}

Muhammad Tayyib Riaz, Institute of Geology,

University of Azad Jammu and Kashmir 13100

Muzaffarabad Pakistan.

tel: +92-312-9042990

e-mail: tayyibriaz@yahoo.com

\section{Acknowledgement:}

The authors are highly grateful to the staff of geotechnical and mineralogical laboratory, Institute of Geology, University of Azad Jammu and Kashmir, Muzaffarabad 13100, Pakistan for their help in performing physico-mechanical tests and other analysis.

\section{How to cite this article:}

Sarfraz, Y., Basharat, M., Riaz, M.T., Khan,

M.A., Shahzad, A. and Ahmed, K.S. (2021).

Evaluation of Physico-Mechanical Properties of Crushed Rock Aggregates: A Case Study from the Sub-Himalaya, Pakistan. Acta Montanistica Slovaca, Volume 26 (3), 466-480

DOI:

https://doi.org/10.46544/AMS.v26i3.07

\begin{abstract}
Geological units of sub-Himalaya Pakistan lying in the core of Hazara Kashmir Syntaxial bend provide vast potential for concrete aggregates in the region. The selection of suiTab. aggregate within active tectonic, fragile lithologic and geotechnical environments is a challenging approach. The present study focused on evaluating the physico-mechanical properties of crushed rock aggregates (CRA) that are already being mined in Muzaffarabad and surrounding areas. For this purpose, integrated physico-mechanical with combined petrographic and mineralogical analysis was performed on dolomite and dolomitic limestone of the Cambrian Muzaffarabad Formation and Eocene Margalla Hill Limestone of Yadgar section. Therefore, samples of aggregates were collected from different quarries in accordance with ASTM standards and their mechanical and engineering properties were evaluated through ASTM and BS standards. The physico-mechanical properties of dolomite and dolomitic limestone conclude that the dolomite rocks have the average strength against abrasion $(25.12 \%)$, impact $(20.75 \%)$ and crushing (19.57\%), higher specific gravity (2.76), lower water absorption $(0.65 \%)$ and higher value of sulphate soundness $(1.5 \%)$. On the contrary, the Margalla Hill Limestone which exhibits average values of abrasion (16.93\%), impact $(22.03 \%)$, crushing $(19.95 \%)$ with lower specific gravity (2.63), high water absorption $(0.68 \%)$, and low values sulphate soundness $(0.77 \%)$. The petrographic investigations showed that chert $3-6 \%$ and granular quartz $25-30$ $\%$ on average are also found in dolomite and dolomitic limestone, which causes the alkali-silica reaction (ASR) and alkali-carbonate reaction (ACR) when used in the concrete. The XRD analysis confirmed that both the formations dominantly contain the minerals dolomite, calcite and quartz. It was also found that Margalla Hill Limestone is more suiTab. to be utilised as coarse aggregate in concrete as compared to dolomite of the Muzaffarabad Formation. These exploitations allow recommending Eocene Margalla Hill Limestone of Yadgar section in the production of the coarse aggregate for concrete.
\end{abstract}

Keywords

Sub-Himalaya, Margalla Hill Limestone, Dolomite, Physicomechanical, XRD. 


\section{Introduction}

Crushed rock aggregates (CRA) have been used in desired sizes for raw material in the construction industry and play a vital role in road and building construction, as in asphalt and cement concrete. Among the raw materials, aggregates are the most sTab. and durable materials present in concrete mixtures, affecting the rigidity of end products. Physical effects, as well as Alkali Silica Reaction (ASR) and Alkali Carbonate Reaction (ACR), compromise the concrete strength if aggregate properties are not up to the required standards, hence, badly affecting the construction quality (Lopez-Buendia et al., 2006). Therefore, knowledge of some aggregate properties (e.g., density, moisture conditions and grading) is essential for amalgamate concrete mixtures. The density, porosity, shape, grading as well as aggregate surface texture determine the characteristics of plastic concrete mixtures. Besides the porosity, the petrographic fabrics of aggregates also alter their hardness, crushing strength, soundness and elastic modulus, which may greatly affect different characteristics of hardened concretes (Fournari and Ioannou, 2019).

Geological constraints of aggregates influence the ultimate strength and durability of concrete, and therefore, aggregates quality utilised in the production of concrete is assumed to be a chief factor in evaluating the compressive strength of concretes (De Brito et al., 2018). Aggregates for concrete are assumed to fulfil the minimal standards of cleanliness (for example, free from deleterious material), durability and strength. Concrete should be free from soft, too porous, chemically active or extremely flaky material because the aforementioned features and the quality of aggregates generally impact the long-term performance of composite building materials (Quiroga and Fowler, 2004). The shape and surface texture of the CRA are fundamental properties in relation to the mechanical bonding effect and their bonding strength in concrete mix design (Adanikin et al., 2018). Olaleye (2012) worked on the relationship of the engineering properties of granitic rock types in Nigeria and concluded that the greater the Rock Quality Designation (RQD) and Uniaxial Compressive Strength (UCS) values, the lesser the Aggregate Crushing Value (ACV), which shows the strong relationships among the RQD, UCS and ACV. The shape of the aggregate is among the key properties regarding aggregate quality. Due to the excessive percentages of flaky particles, the compression strength and workability of cement concrete decrease, whereas the cement consumption increases. On the other hand, packing density, compressive and tensile strength of asphalt concrete decrease (Bouquety et al., 2007). Akbulut and Gurer (2007) investigated that flakiness results in a low tensile strength of asphalt concrete, so aggregates with low percentages of flakiness index should be recommended in asphalt concrete as it promotes deformation. Limestone and dolomite are very worthy raw materials utilised in a vast range, but the construction and cement industries are the principal users. Strategic assessments of local or regional dolomite and limestone resources need to test their integrated physical, mechanical, chemical and mineralogical characteristics. These are the main source of CRA in the cement and construction industry. Enormous reserves of these rocks are present all over Pakistan.

As aggregates constitute $65-80 \%$ of the total volume of concrete, so aggregate characteristics considerably affect the properties and cost effectiveness of fresh and hardened cement concrete (Tugrul and Yilmaz, 2012). The physio-mechanical characteristics of aggregates are presumed to have an effect on the performance and durability of concretes. Certainly, aggregate expends a great impact on concrete hardness and strength, producing stiffness in the hardening state to material which is essential for constructional use (Fournari and Ioannou, 2019). The availability of suiTab. quality and cost-effective aggregates with exploiTab. reserves and uninterrupted supply in the area are important factors for the development of public and private engineering projects. Several researchers have evaluated the properties of limestone to use in construction industries from different localities of Khyber Pukhtunkhwa (KPK) province (Bilqees and Shah, 2007; Jan et al., 2009; Bilqees et al., 2012). Malahat et al. (2018) evaluated different engineering and mineralogical properties of coarse aggregate quarries from KPK to find suiTab. material for aggregates. Ahsan et al. (2009) studied the aggregate characteristics from the Allai area for the reconstruction and rehabilitation of buildings affected by the earthquake in KPK. Naeem et al. (2013) also investigated the mechanical and aggregate characteristics of limestones from Pakistan. However, all these studies were limited to the KPK province of Pakistan.

This study intends to determine the physico-mechanical and petrographic characteristics of CRA fraction for civil engineering projects with the case study of CRA samples from selected quarry sites in district Muzaffarabad. Coarse aggregates are among the main construction material used in asphalt and cement concrete, i.e., > $95 \%$ for asphalt concrete and about 60-75\% for cement concrete. The availability of durable CRA will therefore be the dire prerequisite for the flourishment of the construction industry in the region. The durability of CRA depends on the physico-mechanical and chemical properties. Demand for aggregate is high and will only increase in the future as cities grow and demand infrastructure increases.

Weak materials, particularly CRA in construction, has been characterised as the major causes of structure failures throughout the globe. So, improper selection of CRA for concrete can initiate premature structural failure. Selecting a suiTab. CRA is essential to minimise the frequent problems associated with the building and pavement failures. In numerous ways wherein aggregates are used, it is subjected to a range of stresses, and the structure response in which it is consumed will mainly depend upon the physical and mechanical properties of the CRA. 
So, physico-mechanical and petrographic properties of the CRA should therefore be tested and verified before the concrete mix designs.

Due to rapid increase in the urban area developments and civil infrastructures, demand for the high-quality coarse aggregates increases. Moreover, the 2005 Kashmir earthquake has also damaged the existing buildings and road network badly, which causes many fatalities in the district Muzaffarabad (Basharat et al., 2021). This catastrophic event led to the demand for the best quality aggregates for the safe reconstruction and rehabilitation of the public and private building infrastructures.

The CRA of carbonate rocks of dolomite and limestone exposed in the Muzaffarabad, sub-Himalayas, Pakistan, are being extensively used in the construction industry before and after the 2005 Kashmir earthquake, which may cause deterioration of the engineering structures such as dams, roads, bridges and buildings in the studied area. To address this problem, the present research was conducted to evaluate the physico-mechanical properties of CRA, which is already being mined from the study area. Therefore, the present study includes the physical, mechanical, chemical and petrographic investigation in order to understand the quality of crushed aggregates. The obtained results are helpful to assist the geotechnical engineers in selecting aggregates for various applications depending on their fundamental characteristics.

\section{Geological Settings}

Steep slopes, fragile lithological conditions and active tectonics are the key features of the studied region (Riaz et al., 2018). Tectonically, the study area lies in the northwestern Himalayan fold and thrust belt (Kazmi and Jan, 1997). Due to regional change in the strike, the Hazara Kashmir Syntaxis (HKS) and Nanga-Parbat Syntaxis were developed (Fig. 1). The core of HKS hosts the studied area. The development of HKS is responsible for active tectonics (active faults, deformed folding and fracturing) in the region (Calkins et al., 1975). The geological units in the study area are highly deformed due to Main Boundary Thrust (MBT), Jhelum Fault (JF), Muzaffarabad Fault (MF) and Muzaffarabad Anticline (MA). The stratigraphic succession exposed in the Muzaffarabad area ranges from Precambrian to Recent in age (Baig and Lawrence, 1987). In contrast, the rocks exposed in the study region range from Cambrian to Eocene (Fig. 2). Two carbonate rock units were selected for detailed investigation, including the Muzaffarabad Formation of the Cambrian age and Margalla Hill Limestone of the Eocene age.

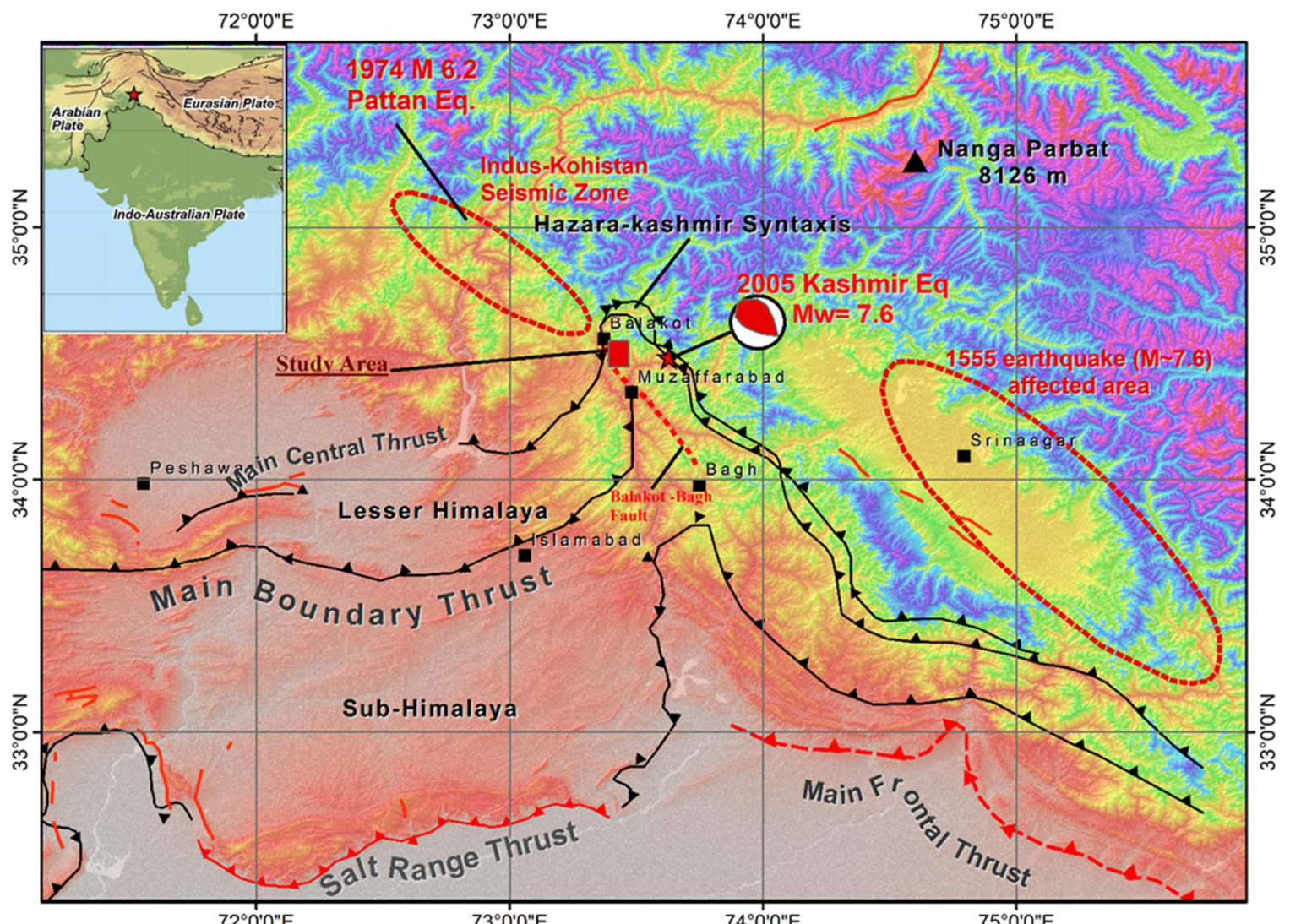

Fig. 1. Regional tectonic map of the frontal Himalayas adopted from Riaz et al. 2018. (Data from Armbruster et al. 1978; Seeber and Armbruster 1979; Nakata et al. 1991; Ambraseys and Jackson 2003; Avouac et al. 2006.) 


\section{Muzaffarabad Dolomite}

The Muzaffarabad Formation comprises various units: black dolomitic limestone and black shale, alternate black chert and light creamish cherty dolomitic bands, stromatolitic dolomite and creamish to light greyish quartzite (Fig. 3a, b, c, d). The assessed thickness of the Cambrian Muzaffarabad Formation is about 800 meters to the upper east of Muzaffarabad (Calkins et al., 1975). Muzaffarabad Formation has lower faulted contact with Miocene Murree Formation whereas, the upper contact is unconformable with Paleocene-Eocene rocks. Muzaffarabad Formation is highly fractured and jointed, cherty, stromatolitic, light to dark grey with tenacity of medium to high scale (Calkins et al., 1975; Baig and Lawrence, 1987; Greco, 1989). Additionally, micro folds were also present in the Muzaffarabad Formation. The nature of fractures in dolomite is conchoidal. Open joints ranging from $2 \mathrm{~mm}$ to $30 \mathrm{~mm}$ were also present. Due to intense fracturing, massive blocks of dolomite were not obtainable (Mustafa et al., 2016).

\section{Margalla Hill Limestone}

About $6 \mathrm{Km}$ from the Muzaffarabad (Capital city), in the Yadgar section, the Margalla Hill Limestone is exposed. The limestone is dark grey to blackish weathered to brown and rusty brown. Margalla Hill Limestone is highly tenacious, nodular, thickly bedded, fractured at some places and texturally fine to medium-grained (Munir et al., 2006). The limestone is 100m thick in the area (Shah, 2009). (Fig 3e, f).

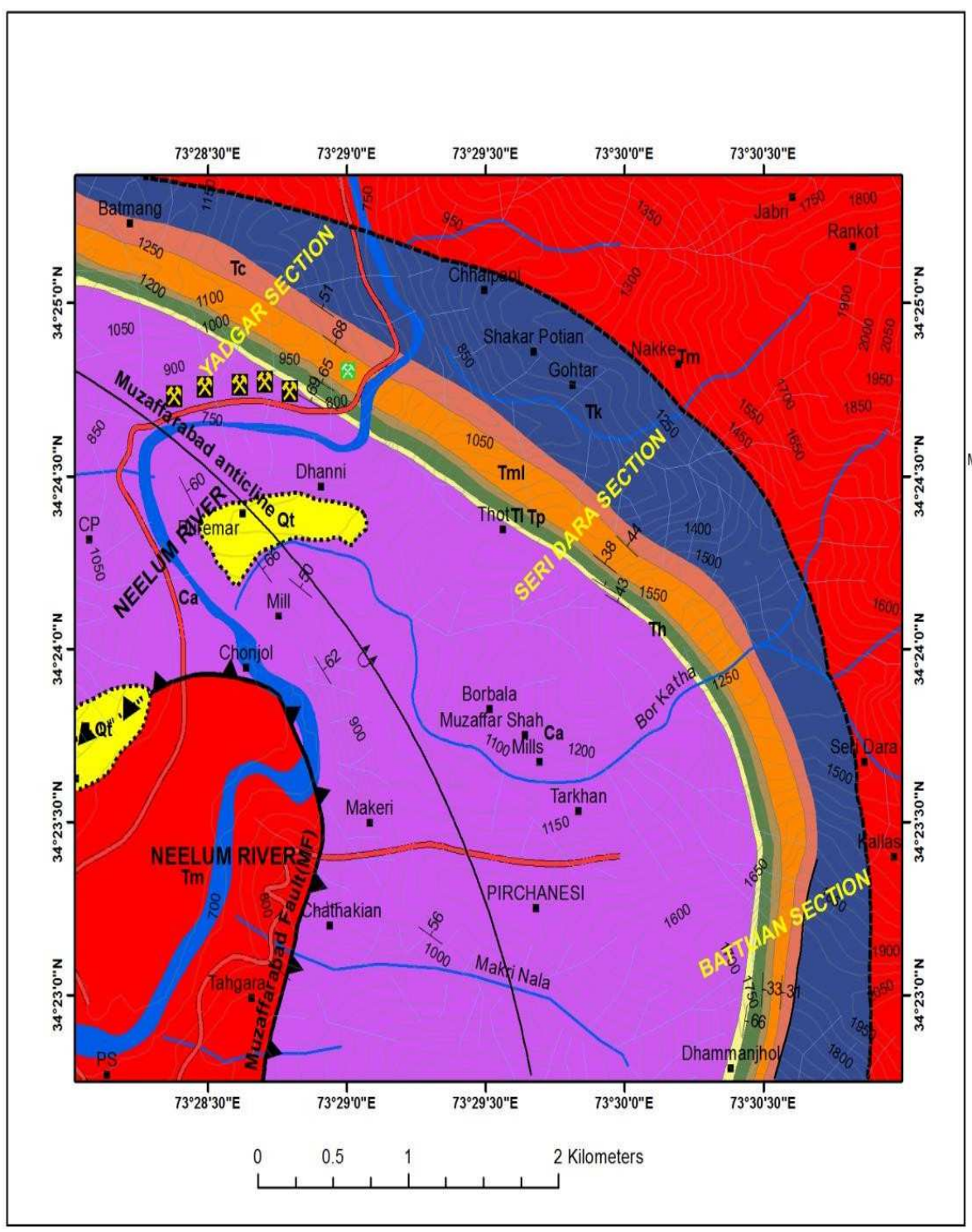

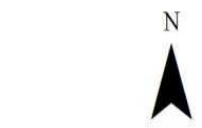

$$
\begin{aligned}
& \text { Recent } \\
& \text { Early Miocene } \\
& \text { Middle to Late } \\
& \text { Eocene } \\
& \text { Early Eocene } \\
& \text { Early }
\end{aligned}
$$

Structural Symbols

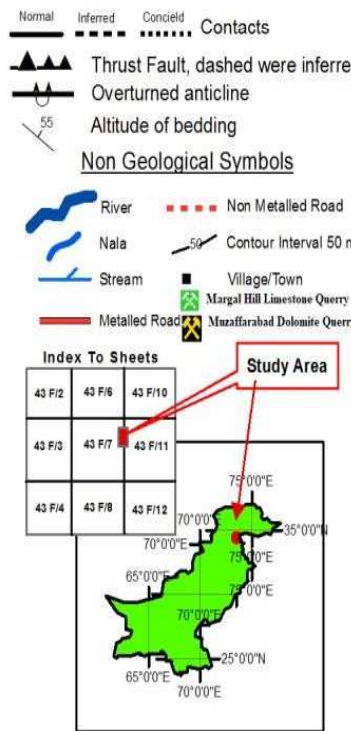

Fig. 2. Geological Map of the study area. 


\section{Material and Method}

This research focuses on integrated study for the characterisation of CRA having different mineralogical/petrographic properties quarried in the Muzaffarabad region. The obtained results are adopted to analyse the possible associations between the different characteristics of the CRA experimented and to emphasise the influencing mechanical as well as mineralogical/petrographic factors affecting the characteristics of tested crushed aggregates. The methods used in this research comprise a review of literature on earlier studies (for example, Malahat et al., 2018; Ahsan et al., 2009) and on basic principles interrelated to the present research.

Field visits of main quarry sites around the Yadgar area were carried out in order to collect samples of CRA of $19-4.75 \mathrm{~mm}$ in size for laboratory testing. Thirty samples of the crushed aggregate of limestone and dolomite were collected from six different active quarry sites (Fig. 2). Based on the fieldwork and laboratory tests performed, the results obtained have been analysed and discussed comprehensively. Finally, the results of the research have been reported and compared with the standard requirements of ASTM and BS using different aggregate qualities. This study was designed in such a way that significant and reliable data on the quality of the aggregates for concrete in Muzaffarabad be suitably evaluated.

\section{Testing Methodology}

Different tests were performed in accordance with ASTM and BS standards. For the determination of the Abrasion value, ASTM C131/C131M was employed using A-Type grading in the Los Angeles abrasion testing machine. Crushing value was estimated via BS 812:110, 812-11 on sample size passing $12.5 \mathrm{~mm}$ sieve and retained on $10 \mathrm{~mm}$ sieve using standard cylinders in a testing machine capable of applying a load of 40 tonnes at a loading rate of 4 tonnes per minute. Impact value test was performed in accordance with BS 812, 112, 1990; 2000 on sample size passing $12.5 \mathrm{~mm}$ sieve and retained on $10 \mathrm{~mm}$ sieve using impact value testing machine. Soundness test for aggregates was carried out via ASTM C88/C88M-18 on sample sizes passing $9.5 \mathrm{~mm}$ and $19 \mathrm{~mm}$ and retained on $4.75 \mathrm{~mm}$ and $9.5 \mathrm{~mm}$ sieves respectively immersed in Sodium Sulphate solution for five cycles each with the duration of 18 hours. For water absorption and relative density, the ASTM C 127 - 07 was used with a sample size of $19 \mathrm{~mm}$ using a wire basket of $4.75 \mathrm{~mm}$ (No. 4).
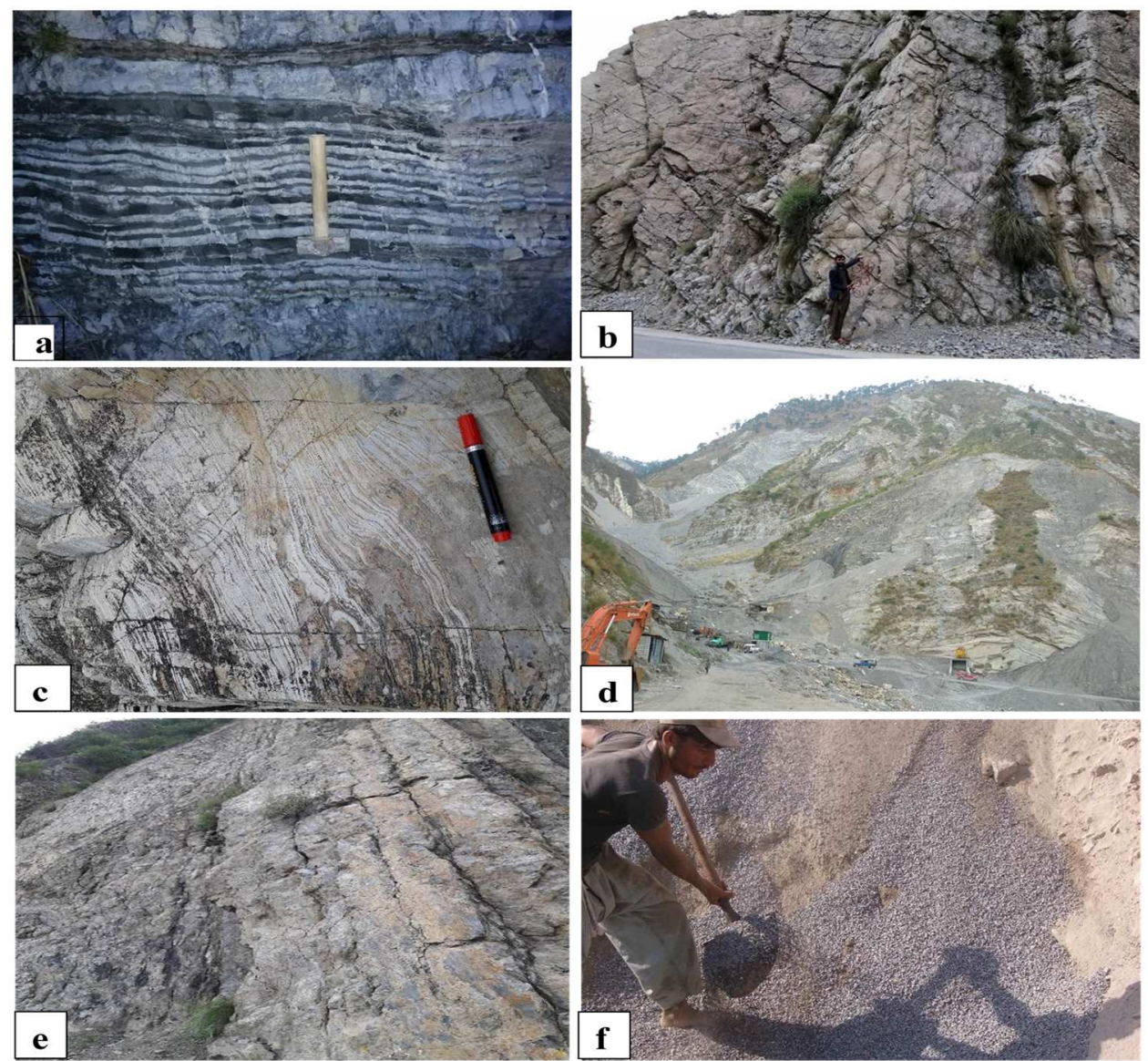

Fig. 3. Field photographs: a) cherty dolomitic bands of the Muzaffarabad Formation; b) Stromatolitic Dolomite; c) Thin fenestral laminated dolomitic limestone ; d) A view of Muzaffarabad Formation quarry near Yadgar area; e) Steeply bedded Margalla Hill Limestone at Yadgar area and f) Dust particles produced by the crushing and through surface runoff during heavy rainfall in the Margalla Hill Limestone. 
Particle size distribution was estimated by ASTM C136 - 06. Petrographic and mineralogical assessments of carbonate aggregates were also performed to know the relative percentages of constituent minerals. Qualitative and semi-quantitative Powder X-Ray Diffraction (PXRD) mineralogical analyses were also carried out on 2 samples of the Muzaffarabad dolomite and 1 sample of the Margala Hill Limestone. The methodological steps adopted for the current study is illustrated in Fig 4.

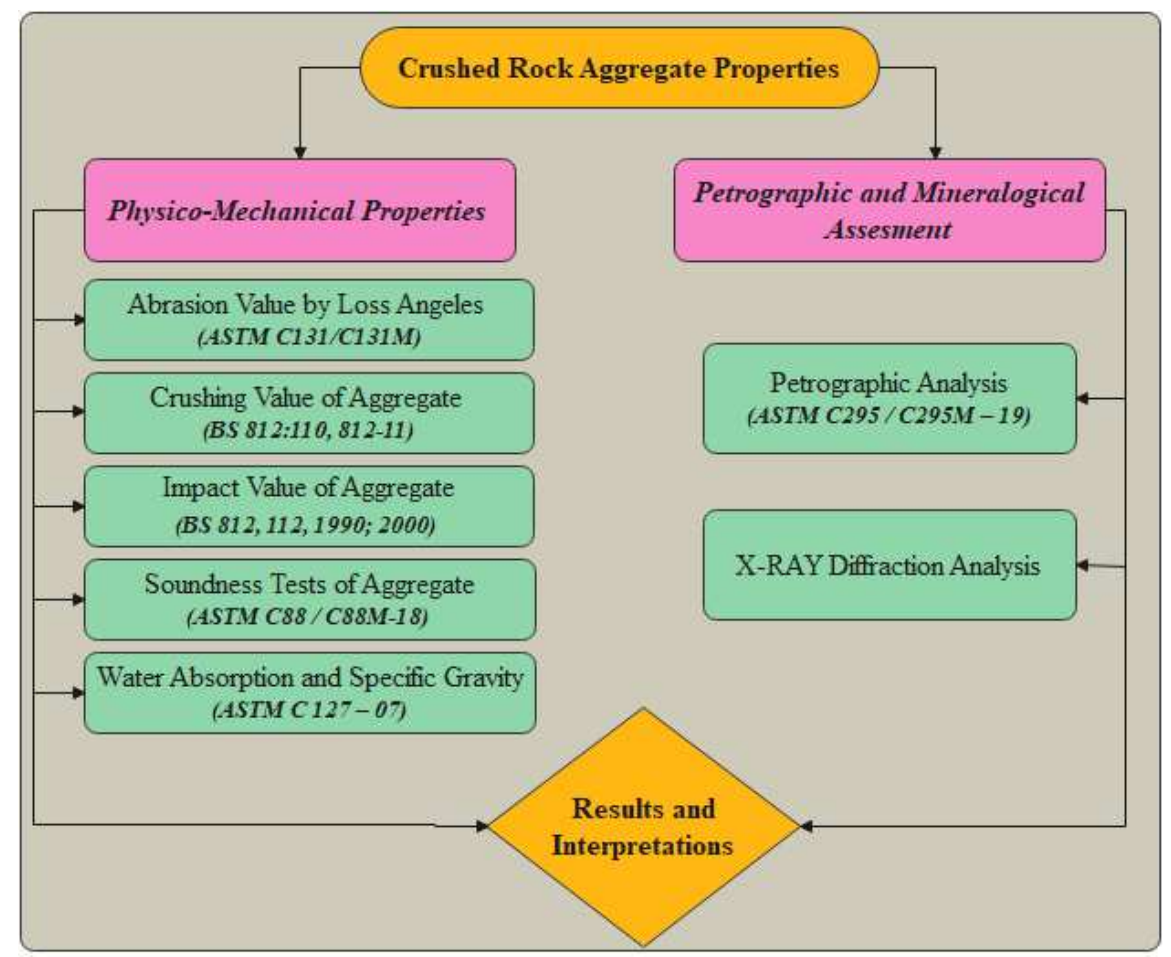

Fig. 4. Methodological flow chart for current research work.

\section{Results and Discussion}

The average values of the test results were compared to the appropriate ASTM and BS standards for each kind of test in order to characterise the physico-mechanical properties of the aggregate examined in this study. The appropriateness and quality of aggregates for concrete usage are assessed based on this comparison.

\section{Abrasion value by Los Angeles (LAAV)}

To evaluate the durability and toughness of crushed rock aggregate, a test for LAAV was performed on collected samples. The allowable limits for the abrasion value as specified in the test method ASTM C131/C131M is $0 \%$ to $50.0 \%$. The abrasion values of dolomite and dolomitic limestone of the Muzaffarabad Formation is 20.33 $\%-32.12 \%$, which fall within the ASTM specified limits (Tab. 1; Fig. 5a). The abrasion values of the Margalla Hill Limestone are $15.27 \%-19.8 \%$. These values are well within ASTM requirements and indicate the suitability of the limestone as concrete aggregate (Tab. 2; Fig. 5b). The Margalla Hill Limestone and the Muzaffarabad Formation from the study area meet the ASTM and BS standard limits for LAAV. However, Muzaffarabad Formation cannot be used in cement concrete as it possesses high silica content (i.e. chert) and dolomite as per petrographic and XRD analysis, which shows its affinity towards ASR and ACR. So, based on the petrographic and chemical analysis, Margalla Hill Limestone is the best selection for the cement concrete in the area.

\section{Crushing value of aggregate (ACV)}

The strength against crushing is among the most vital mechanical property which should be considered while the crushed aggregate selection for engineering projects (BS 812:110,812-11). The ACV shows the comparative measure of its resistance against crushing under progressively applied load. This property has a significant role in the quality and strength of the concrete. Low values of crushing show durable aggregates and vice versa.

The dolomite and dolomitic limestone of the Muzaffarabad Formation show considerable deviations in their strength against crushing strength. The values range from $17.30 \%$ to $22.76 \%$ (Tab. 1; Fig. 5a). These values are within the BS standard requirements i.e. 0 - $30 \%$ (BS 812:110,812-11). The variations in crushing values are due to the lithologic changes, weathering effects and natural crushing due to jointing, fracturing and faulting. 
The crushing values of the Margalla Hill Limestone range from $17.93 \%$ to $24.9 \%$ (Tab. 2; Fig. 5b). Comparatively, the loss percentages of crushing values of the dolomite and dolomitic limestone of the Muzaffarabad Formation are considerably greater than the Margalla Hill Limestone in the area.

\section{Impact value of aggregate (AIV)}

The impact value of the aggregate is a measure of its resistance and toughness against sudden impact or shock. The value is of considerable significance for aggregates used in roads, airstrips and other infrastructures. Aggregates were classified as weak, satisfactory and strong for road surfacing based on AIV. BS Standard Limits for AIV for cement concrete is 0 to $30 \%$ (BS 812, 112, 1990; 2000). The loss percentage of AIV in dolomite and dolomitic limestone aggregate of the Muzaffarabad Formation ranges from $14.86 \%-25.76 \%$ (Tab. 1; Fig. 5a). The loss percentage of AIV of the Margalla Hill Limestone ranges from $15.54 \%-25.72 \%$ (Tab. 2; Fig. 5b). These differences in the impact value can be attributed to the rock fractures, joints, filled materials and intensity of weathering. The low AIV shows strong aggregate and vice versa. Aggregate resistance to sudden impact is considered to be very crucial in pavement construction. The CRA possessing AIV percentage less than 10 per cent is considered as very strong while greater than 35 per cent is regarded as very weak for the road surface materials. Due to heavy traffic, the aggregates used in the road pavements are exposed to the grinding action/impact, and hence there is a possibility of deterioration of the aggregates, which in turn weakens the road structure. Therefore, CRA used in the road pavements should be strong enough to resist load impact. The AIV obtained for the Margalla Hill Limestone and Muzaffarabad Dolomite crushed aggregates are less than the standard limits. Both CRA are therefore appropriate for road construction and other engineering works.

\section{Soundness tests of aggregate}

The aggregate soundness incorporates the inclusive stability of the rock aggregates against chemical weathering. The soundness values are achieved by immersion and successively drying in the $\mathrm{Na}_{2} \mathrm{SO}_{4}$ solution in 5 successive cycles. The ASTM specification (ASTM C88/C88M-18) is $12 \%$ for base coarse and $10 \%$ for cement concrete. The soundness test values of the Muzaffarabad Formation dolomite range from 1.09 to $1.96 \%$, whereas limestone range from 0.47 to $1.14 \%$ (Tab. 1 and 2; Fig. 6a). These values show that the Margalla Hill Limestone is relatively more resistant to the weathering action than the Muzaffarabad Formation Dolomite.

\section{Water absorption and specific gravity}

Specific gravities can differ extensively depending upon the type of aggregate. It measures the extent of quality and strength of rock aggregates according to ASTM C $127-07$. The specific gravity of aggregates of the Muzaffarabad Formation ranges from 2.62 to 2.89, while the values of water absorption range from $0.43 \%$ to $0.98 \%$. The specific gravity of the Margalla Hill Limestone aggregate ranges from 2.52 to 2.73 , while the water absorption values range from $0.53 \%$ to $0.83 \%$ (Tab. 1 and 2 ; Fig. $6 \mathrm{~b}$ ). These values fall within the ASTM specification limits. These values indicated that the Margalla Hill Limestone is better than Muzaffarabad Formation Dolomite for concrete mix.

\section{Petrographic Characteristics of the Aggregates}

The petrographic study of the rock aggregates of the Muzaffarabad Formation and the Margalla Hill Limestone from different localities were performed to classify the aggregates under study to evaluate their chemical reactivity. To determine the type and amount of the constituent minerals in the samples, aid in assessing the properties of aggregate that impact the reactivity of the aggregate in concrete (ASTM C295/C295M - 19).

\section{Petrography of Muzaffarabad Formation}

Petrographically, the Muzaffarabad Formation is dominantly composed of carbonate minerals calcite and dolomite followed by the mineral quartz and traces of hematite, pyrite and mica. The modal composition of the Muzaffarabad Formation is 30-50\% dolomite, 30-35\% calcite, 15- 25\% detrital quartz, 5-7\% bioclasts, 3-6\% chert and traces of hematite, pyrite and micas. So, it is evident that other than carbonate minerals, the formation contains considerable quantities of quartz. It is found as cherty dolomite and quartzite at different levels of the formation. The amount of chert in dolomite and dolomitic limestone ranges from $3 \%$ to $6 \%$ (Fig. 7a, b, c, d, g). Chert in aggregate produces ASR, which causes deterioration of cement concrete. Moreover, the mineral dolomite also bears the ACR potential. The iron sulphide, i.e. pyrite, oxidises rapidly, reduces strength and causes staining of concrete. Silts and clays fractions are also found in various samples, which lead to increased water requirements of the concrete mix, hence decreasing the durability of the composite material. The quartz generally enhances the mechanical properties of rock aggregate due to its higher hardness. But chemically reactive quartz causes the ASR in concrete over time.

\section{Petrography of Margalla Hill Limestone}


Petrographically, the Margalla Hill Limestone is mainly wackestone which contains the modal composition as $50-65 \%$ calcite, $20-30 \%$ micrite, $10-15 \%$ bioclasts, with a minor amount of dolomite and detrital quartz and traces of hematite and pyrite (Fig.7 e,f). Clay is also present in limestone as a matrix ranging from $0.5 \%$ to $1 \%$. It weakens the aggregate-cement bond and is regarded as deleterious material in concrete. The quartz is found in limestone as a detritus material and varies from $1 \%$ to $3 \%$ (Fig. 7e, f). Minor quantity of hydrous silica in the Margalla Hill Limestone aggregate have the potential to result in expansion and fast deterioration of the concrete.

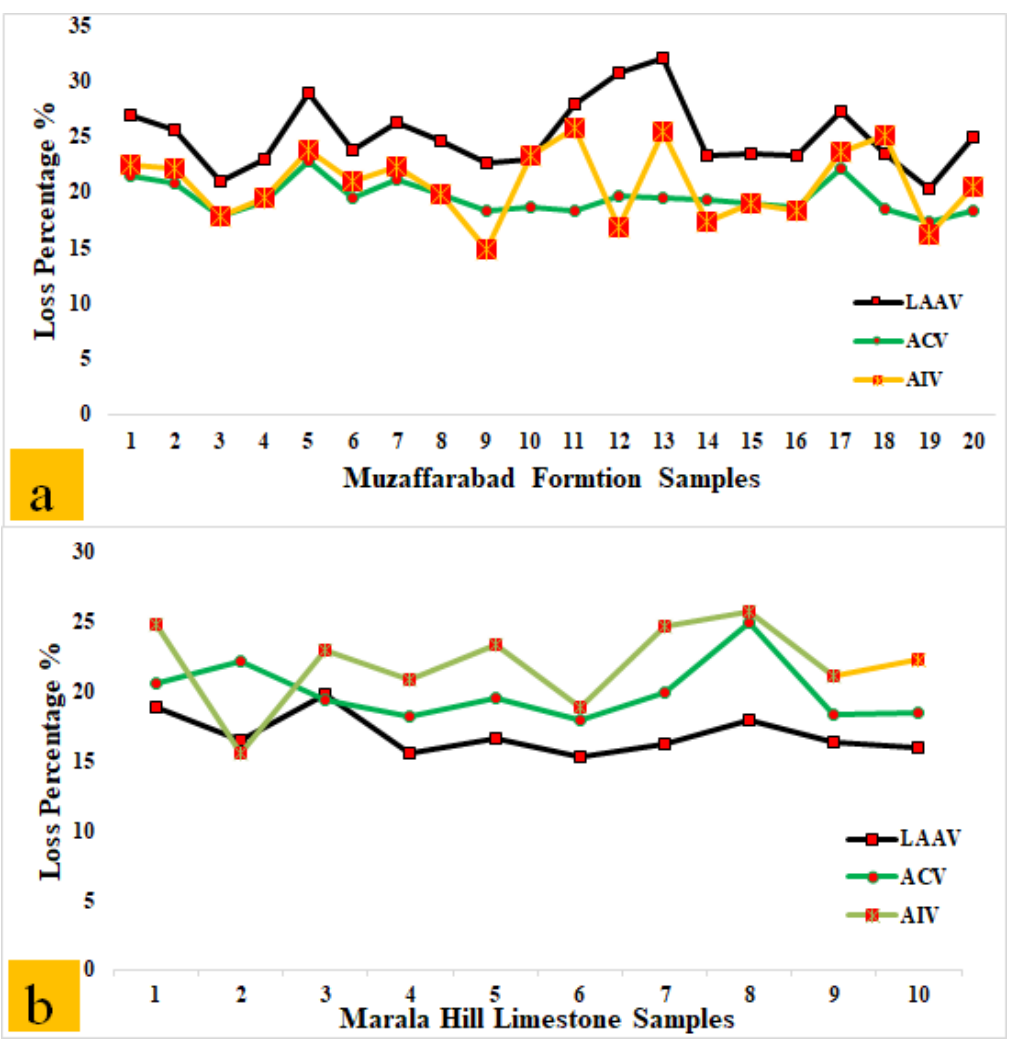

Fig. 5. Comparison of physico-mechanical properties a) comparison between LAAV, ACV and AIV of Muzaffarabad Formation b) comparison between LAAV, ACV and AIV of Margalla Hill Limestone

\section{X-Ray Diffraction Analysis}

The X-Ray diffraction analysis aid to determine the crystalline nature, phase composition as well as percentage of mineral constituents. Three selected rock samples, two from the Muzaffarabad Formation and one from the Margalla Hill Limestone, were selected, crushed into powder and examined under an X-Ray diffractometer for bulk rock mineralogy. The analysis shows that the Muzaffarabad Formation is dominantly composed of the mineral calcite, which ranges from 38-79\% and dolomite $0-36 \%$, followed by quartz $12-26 \%$. The high percentage of quartz and dolomite shows that the rock aggregate from Muzaffarabad Formation possesses a high potential of ASR and ACR when used in Portland cement concrete; the standards ASTM limits for dolomite and quartz being 5-7\% for coarse aggregate. Similarly, the Margalla Hill Limestone shows mineral calcite 93\% and quartz 7\%. The XRD analysis was done to confirm the mineralogy of the Muzaffarabad Formation and the Margalla Hill Limestone. The analysis shows that both formations are dominantly composed of the mineral calcite, dolomite, followed by quartz (Fig.8a, b, c). 


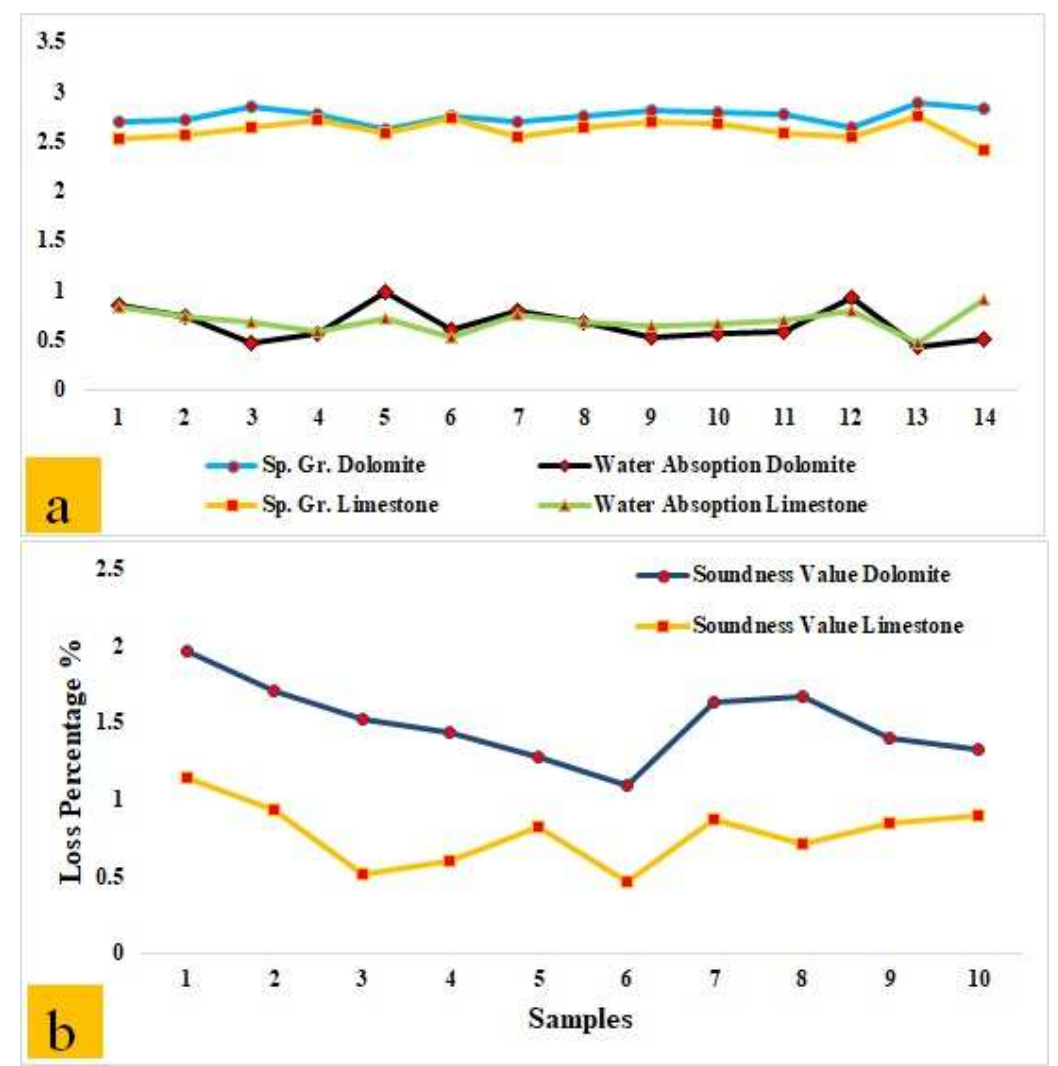

Fig. 6. Comparison of Physico-mechanical properties a) comparison between aggregate soundness values of Muzaffarabad Formation and Margalla Hill Limestone b) comparison between Specific Gravity and Water Absorption of Muzaffarabad Formation and Margalla Hill Limestone.

\section{Results Interpretation}

The investigated rock units varied in structure, texture, colour and mechanical properties. The physicomechanical characteristics of the Margalla Hill Limestone represent that this rock unit is tough, durable and hard, having good strength characteristics. Hence, Margalla Hill Limestone of the studied sections is appropriate for road pavements and Ordinary Portland/Reinforced Cement Concrete (PCC/RCC). Quarriable reserves of limestone were present in Batmang locality; however, careful planning is essential to build up the quarries for local civil construction needs. The specific gravity of the Margalla Hill Limestone suggests that it can be used in lightweight cement concrete for low to medium traffic loads and heavy building constructions. Due to the low water absorption values of limestone, it can be used for high strength asphalt and cement concrete. The behaviour of the Margalla Hill Limestone against different cycles of the LAA test refers to that it resists the wear and tear against the traffic loads, which enhances the pavement strength against degradation. The crushing values of the limestone depict its resistance and remain sTab. against the load variations when used as road aggregates. Low loss values also enhance the compressive strength of concrete. The low impact value of limestone also refers to the suitability of the limestone to be used as wearing course and base course for the road pavements. It showed the significant resistance against wearing and have the ability to bear heavy loads.

Tab. 1. Summary of Physicomechanical properties of Muzaffarabad Dolomite crushed aggregate.

\begin{tabular}{|c|c|c|c|c|c|c|c|}
\hline Material & Sample ID & Specific Gravity & $\begin{array}{c}\text { Water Absorption } \\
\%\end{array}$ & $\begin{array}{c}\text { Loss Angeles } \\
\text { Abrasion } \\
\text { Values } \% \\
\end{array}$ & $\begin{array}{c}\text { Sodium } \\
\text { Sulphate } \\
\text { Soundness \% } \\
\end{array}$ & $\begin{array}{l}\text { Aggregate } \\
\text { Crushing } \\
\text { Value \% } \\
\end{array}$ & $\begin{array}{c}\text { Aggregate } \\
\text { Impact } \\
\text { Value } \% \\
\end{array}$ \\
\hline \multirow{7}{*}{ 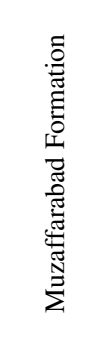 } & YMF-01 & 2.69 & 0.86 & 26.93 & 1.96 & 21.42 & 22.54 \\
\hline & YMF-02 & 2.71 & 0.74 & 25.54 & -- & 20.75 & 22.16 \\
\hline & YMF-03 & 2.84 & 0.48 & 20.93 & -- & 17.82 & 17.8 \\
\hline & YMF-04 & 2.78 & 0.57 & 22.94 & 1.32 & 19.15 & 19.45 \\
\hline & YMF-05 & 2.62 & 0.98 & 28.89 & -- & 22.76 & 23.86 \\
\hline & YMF-06 & 2.76 & 0.61 & 23.82 & 1.7 & 19.54 & 20.9 \\
\hline & YMF -07 & 2.75 & 0.68 & 26.28 & -- & 21.1 & 22.35 \\
\hline
\end{tabular}




\begin{tabular}{|c|c|c|c|c|c|c|}
\hline YMF -08 & -- & -- & 24.64 & 1.52 & 19.88 & 19.82 \\
\hline YMF -09 & 2.79 & 0.56 & 22.67 & 1.44 & 18.4 & 14.86 \\
\hline YMF - 10 & 2.64 & 0.92 & 22.89 & -- & 18.6 & 23.28 \\
\hline YMF - 11 & 2.89 & 0.43 & 28 & -- & 18.32 & 25.76 \\
\hline YMF - 12 & 2.83 & 0.51 & 30.75 & 1.27 & 19.67 & 16.89 \\
\hline YMF - 13 & -- & -- & 32.12 & 1.09 & 19.52 & 25.4 \\
\hline YMF - 14 & 2.78 & 0.57 & 23.35 & -- & 19.4 & 17.4 \\
\hline YMF - 15 & 2.81 & 0.52 & 23.52 & -- & 19.02 & 18.95 \\
\hline YMF - 16 & -- & -- & 23.21 & -- & 19.67 & 18.3 \\
\hline YMF -17 & 2.77 & 0.59 & 27.31 & 1.63 & 22.2 & 23.58 \\
\hline YMF - 18 & -- & -- & 23.52 & 1.67 & 18.54 & 25.18 \\
\hline YMF -19 & 2.7 & 0.8 & 20.33 & -- & 17.3 & 16.24 \\
\hline YMF-20 & -- & -- & 24.91 & 1.4 & 18.37 & 20.4 \\
\hline
\end{tabular}

Tab. 2. Summary of Physicomechanical properties of Margala Hill Limestone crushed aggregate.

\begin{tabular}{|c|c|c|c|c|c|c|c|}
\hline Material & Sample ID & Specific Gravity & $\begin{array}{c}\text { Water } \\
\text { Absorption \% }\end{array}$ & $\begin{array}{c}\text { Loss Angeles } \\
\text { Abrasion } \\
\text { Values \% }\end{array}$ & $\begin{array}{c}\text { Sodium } \\
\text { Sulphate } \\
\text { Soundness \% }\end{array}$ & $\begin{array}{l}\text { Aggregate } \\
\text { Crushing } \\
\text { Value } \%\end{array}$ & $\begin{array}{c}\text { Aggregate } \\
\text { Impact } \\
\text { Value } \% \\
\end{array}$ \\
\hline \multirow{10}{*}{ 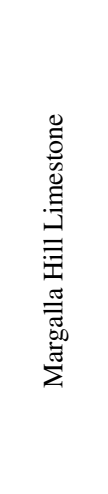 } & MHL-01 & 2.52 & 0.83 & 18.89 & 1.14 & 20.62 & 24.8 \\
\hline & MHL-02 & 2.57 & 0.73 & 16.55 & 0.93 & 22.19 & 15.54 \\
\hline & MHL-03 & 2.63 & 0.69 & 19.8 & 0.51 & 19.36 & 22.92 \\
\hline & MHL-04 & 2.71 & 0.58 & 15.64 & 0.6 & 18.26 & 20.85 \\
\hline & MHL-05 & 2.58 & 0.72 & 16.66 & 0.82 & 19.54 & 23.4 \\
\hline & MHL-06 & 2.73 & 0.53 & 15.27 & 0.47 & 17.93 & 18.9 \\
\hline & MHL-07 & 2.55 & 0.76 & 16.21 & 0.87 & 19.88 & 24.75 \\
\hline & MHL-08 & 2.64 & 0.68 & 17.95 & 0.71 & 24.9 & 25.72 \\
\hline & MHL-09 & 2.7 & 0.64 & 16.35 & 0.84 & 18.32 & 21.16 \\
\hline & MHL-10 & 2.67 & 0.66 & 16.02 & 0.89 & 18.52 & 22.3 \\
\hline & \multicolumn{7}{|c|}{ MHL= Margalla Hill Limestone } \\
\hline
\end{tabular}

The physico-mechanical properties of Muzaffarabad dolomite of studied areas revealed that it fulfils ASTM standard limits for road construction. The specific gravity of the Muzaffarabad dolomite showed that dolomite also possesses the potential to be used as coarse aggregate for lightweight concrete. It can be used as road aggregate for asphalt concrete but should carefully be used as cement concrete aggregate due to the presence of dolomite crystals and chert. High values of water absorption may affect the strength of concrete produced. These high water absorption values indicate that this dolomite will deteriorate the cement concrete due to ASR and ACR potential. 

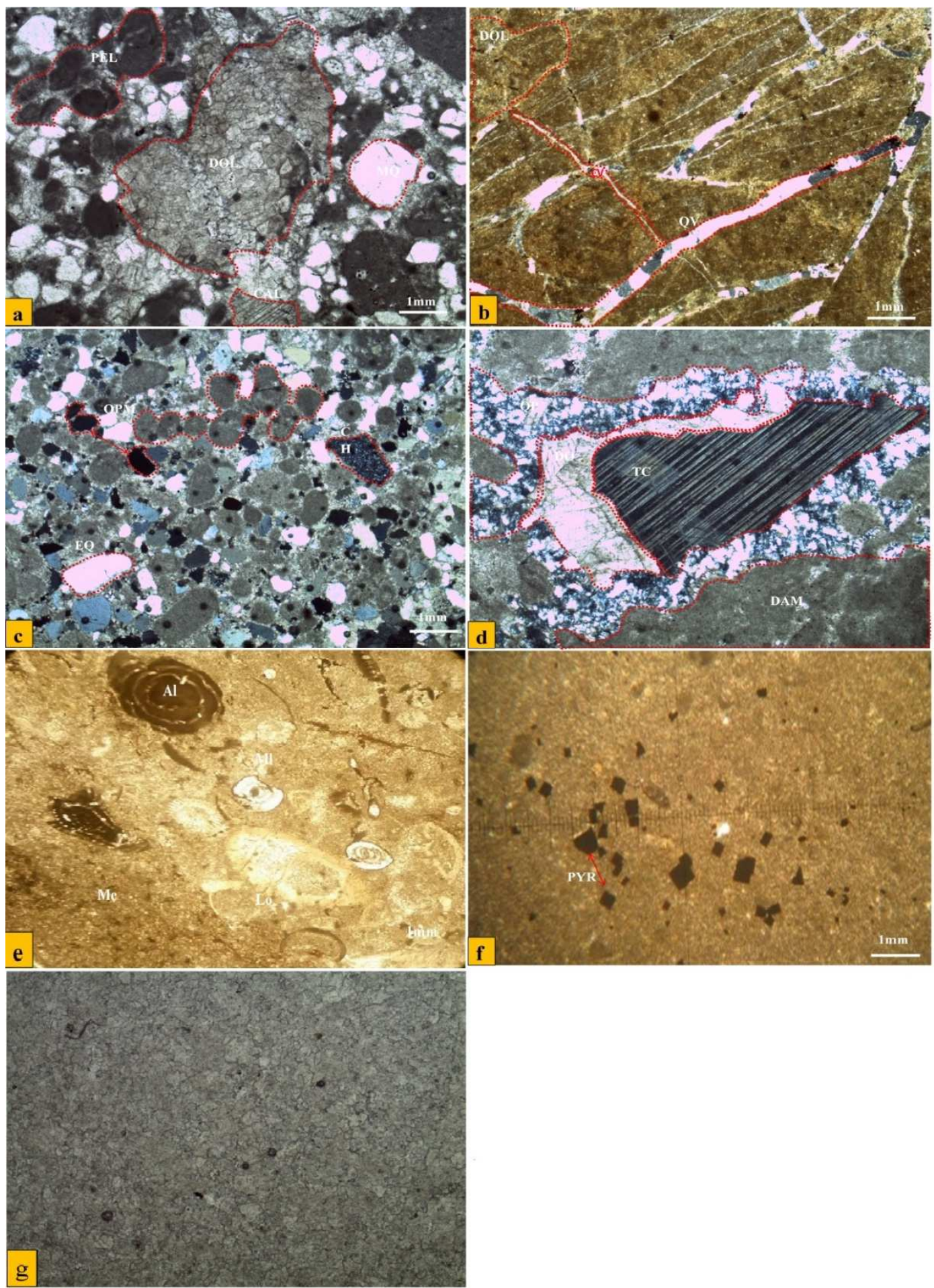

Fig. 7. Photomicrograph of Muzaffarabad Formation a) showing Peloids (PEL), dolomite (DOL), microcrystalline quartz (MC), calcite $(C A L)$. b) showing multisets of quartz filled veins in dolomite unit c) showing peloids (PEL), opaque mineral (OP), chert (CH) and elongated quartz $(E Q)$ d) showing dolomite $(D O)$, twin calcite $(T C)$ and dolomitised algal mat (DAM); Photomicrograph of Margalla Hill Limestone e) showing bioclastic limestone, Lokhartia $(L O)$, miliolids $(M L)$, micrite $(M C)$ and Alveolina $(A L) f)$ showing micritic limestone, pyrite $(P Y R) . g)$ Photomicrograph shows nonplanar coarse crystalline dolomite.

LAAV of Muzaffarabad dolomite fulfils the ASTM standard limit but results in the loss in size and compressive strength of concrete compared to the Margalla Hill Limestone. High loss percentages suggest that dolomite can be used for low traffic surfaces. During crushing, this will produce more dust which will affect the environment as well. Low loss percentages of ACV of the Muzaffarabad dolomite aggregate indicate that the rock unit can be used in road surfaces and asphalt concrete. It also refers to high compressive strength hence, enhancing the durability of road pavement. Results of AIV of the Muzaffarabad Formation dolomite refer that the rock unit is resistant enough against fracturing under impact. So, on these grounds, the Muzaffarabad Formation dolomite is regarded as strong to be used as road aggregate. Soundness test values of the studied rock units showed that the 
Margalla Hill Limestone is more resistant to weathering as compared to the Muzaffarabad Formation dolomite. Therefore, Margalla Hill Limestone is less likely to degradation and pavement failure when used in cement and asphalt concrete. Loss percentages in the soundness of dolomite may affect significantly when used in mass concreting.

Petrographic analyses of studied rock units revealed the presence of pyrite, which oxidise rapidly hence, reduction in strength of concrete. The acid by-products subsequent to this chemical reaction are detrimental to concrete. The presence of carbonates, sulphates, phosphates, chlorides, and other chemical salts in the combination of silt and clay may extremely affect the setting up of concrete. In concrete mix presence of clays and silts be liable to increase the water supplies, therefore decreasing the durability of the final product.

\section{Discussion}

Aggregate exhibits different chemical and physical characteristics which govern their appropriateness as a construction and building material (Naeem et al., 2014). Source rock characteristics directly influence the quality of an aggregate (Koukis et al., 2007). Nevertheless, of how an aggregate is utilised, its lithological/geological constraints affect its quality (Hartley 1974; Lees and Kennedy 1975; Smith and Collis 2001). The engineering/physio-mechanical characteristics of crushed rock aggregates are the effects of lithological history, i.e., source rock origin and post-depositional processes, for example, folding, faulting, fracturing, weathering, and hydrothermal alteration. Based on physical/ mechanical properties and logistic cost, different rock units can be utilised as crushed aggregate material, but limestone and dolomite are the most important ones. As the aggregates hold the majority of concrete volume thus, their engineering, chemical, and petrographic/mineralogical properties incredibly influence the concrete quality (Neville, 2000).

Crushed aggregate properties, i.e. strength, size, shape, and water absorption, affects water requirements, the amount of cement and fine aggregate in cement concrete. The larger the crushed aggregate size, the lower the water requirement in the concrete because it has a lower surface area as compared to smaller sized crushed aggregate. Rounded shape aggregate produces an economical concrete mix for average strength concrete. Numerous researchers have studied the physico-mechanical properties of crushed aggregates for the assessment of their suitability. Mineralogy, texture, degree of alteration and weathering of aggregate rocks are the leading causes that affect the physico-mechanical properties, and thus, their suitability for various constructions. The cause of concrete deterioration can often be seen through microscopy of the aggregate materials. The current study focused on evaluating the physico-mechanical and petrographic characteristics of widely used crushed aggregates of Muzaffarabad dolomite and Margalla Hill Limestone of the Muzaffarabad region. For this purpose, several engineering tests were performed, and the petrographic assessment was also carried out to understand the mineralogical composition of these aggregates better. The examined samples fulfil the required standards of ASTM and BS. The specific gravity of crushed dolomite aggregates ranges from 2.62 to 2.89 , while the water absorption values range from $0.43 \%$ to $0.98 \%$. Margalla Hill Limestone aggregates having specific gravity ranges from 2.52 to 2.73, which are nearly in line with the values of Naeem et al. (2014), who observed the specific gravity (2.60-2.63) of Margala Hill Limestone from other regions of Pakistan. Water absorption of crushed aggregates of the Margalla Hill Limestone ranges from $0.53 \%$ to $0.83 \%$, which are less than the values of water absorption (0.94-1.61) of limestone investigated by Naeem et al. (2014). This reveals that the Margalla Hill Limestone fulfils water absorption standards to be utilised in cement concrete. More than $3.0 \%$ values of water absorption of aggregates are susceptible to freeze-thaw action (Shakoor et al., 1982). According to ASTM-127, water absorption should be $<2.5 \%$ for aggregates to be utilised in cement concrete.

According to Smith and Collis (2001), AIV is a test that yields direct measures concerning the pulverisation resistance of an aggregate against impact and sudden shock. The loss percentage of AIV in dolomite and dolomitic limestone aggregate of the Muzaffarabad Formation ranges from $14.86 \%-25.76 \%$, while the loss percentage of AIV of the Margalla Hill Limestone ranges from $15.54 \%-25.72 \%$ are within BS 812 standard limits for cement concrete. Abrasion resistance of aggregates is measured via LAV. Less LAV depicts material durability. The Abrasion values of dolomite and dolomitic limestone of the Muzaffarabad Formation is $20.33 \%-32.12 \%$, which fall within the ASTM specified limits. The abrasion values of Margalla Hill Limestone are $15.27 \%-19.8 \%$, which are less than the LAV (23.93-25.12\%) for limestone investigated by Naeem et al. (2014). These values reveal that these aggregates can be utilised as road aggregate material.

The mineralogical composition of the source rock is associated with aggregate mechanical behaviour. Petrographic analysis of the Margalla Hill limestone indicates that limestone is dominantly comprised of calcite, micrite and bioclasts with traces of dolomite, detrital quartz, hematite and pyrite. Generally, minor calcite presence does not affect Los Angeles abrasion values of aggregates.

However, bioclasts and micrite affect the mechanical characteristics of aggregates. Due to relatively higher percentages of bioclasts (10-15\%) and micrite (20-30\%), the Margalla Hill limestone has comparatively negative impacts on mechanical properties. Muzaffarabad Formation dominantly contains dolomite, calcite, detrital quartz, chert and traces of hematite, pyrite and micas. In addition, with carbonate minerals, the dolomite contains much 
amount of quartz. Chert is also present in a considerable amount which is enough to produce ASR, which causes deterioration of cement concrete. Moreover, the mineral dolomite also bears the ACR potential. The iron sulphide, i.e., pyrite, oxidise rapidly, reduces strength and causes staining of concrete. Silts and clays fractions are also found in various samples, which lead to increased water requirements of the concrete mix, hence decreasing the durability of the composite material.

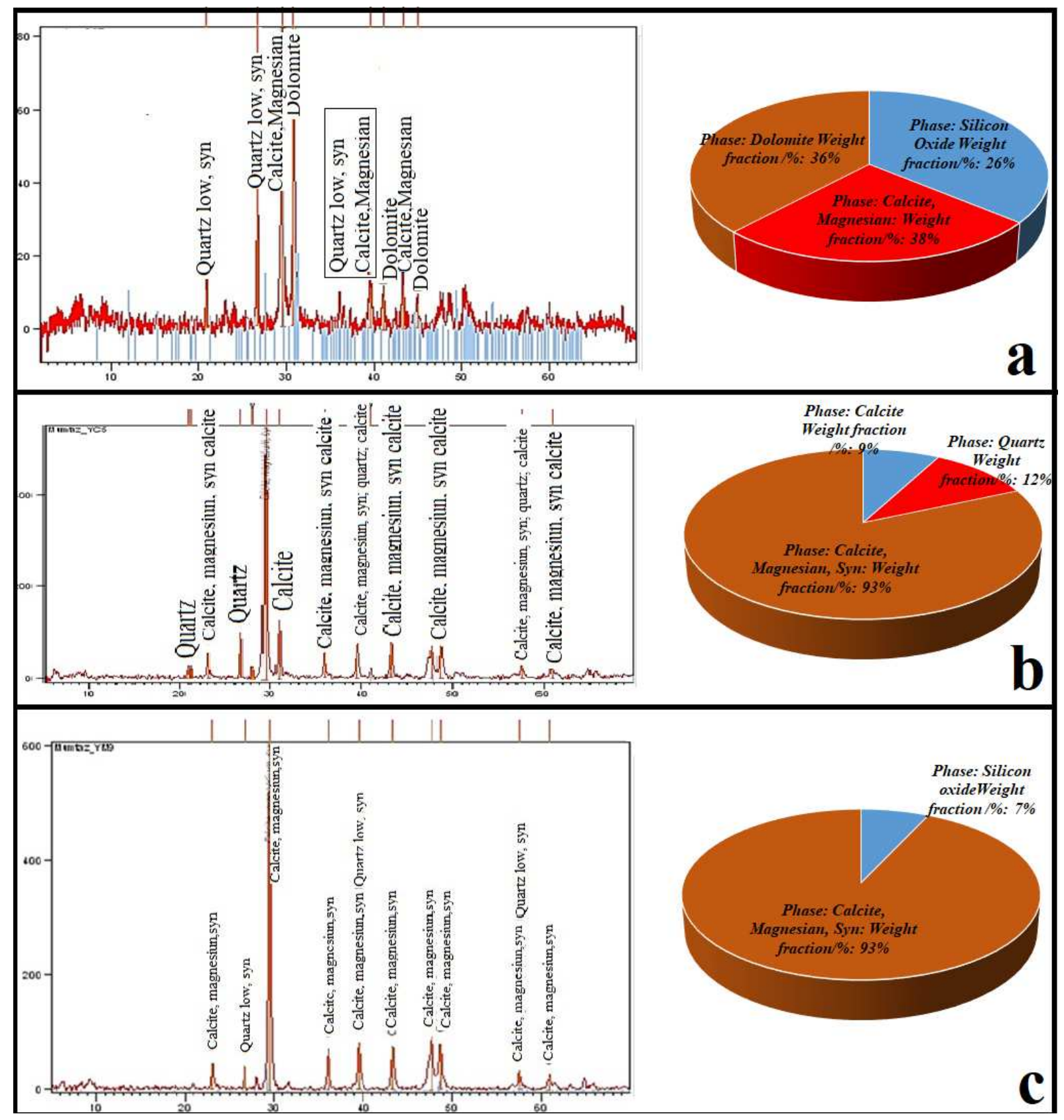

Fig. 8. Graphical and quantitative distribution of X-Ray Diffraction analysis. a,b) Muzaffarabad Formation, c) Margalla Hill Limestone.

\section{Conclusion}

Strong aggregate with a low water absorption percentage, i.e. 1-3\%, is considered good enough for high strength concrete. The water absorption percentage values is an excellent indicator of the aggregate strength and vice versa. So, the moisture content of the aggregate will influence the water content (WC), which in turn also has an impact on the water-cement ratio in concrete. Moreover, this WC affects the proportion of aggregate in the concrete mix as it contributes to the weight of the coarse aggregate used in the concrete. Samples with higher water absorption values possess a low strength as compared to the samples with lower water absorption values. Dolomite and dolomitic limestone of the Muzaffarabad Formation fulfils the required ASTM / BS standard limits of physical, 
mechanical and textural properties. However, it contains a significant percentage of chert (i.e. 3-6\%) which is enough to initiate ASR in cement concrete. Moreover, the dolomite unit also bears the potential of ACR in cement concrete. The obtained results of the Muzaffarabad Formation show High LAV (25-32\%), high AIV (20-25\%), high ACV (20-22\%) and high water absorption values (0.74-0.98\%), represent the quarries which are placed near to the MF zone and show high percentages of micro-fractures observed in petrography. The lower LAV (20-25\%), AIV (14-20\%), ACV (17-20\%) and water absorption values (0.43-0.7) indicate the quarries which are located away from the MF zone while fewer microfractures were also observed in petrography. Moreover, the XRD analysis also concludes that the Muzaffarabad Formation has a significant amount of dolomite and quartz. So, on the basis of petrography and XRD analysis, crushed aggregates of the Muzaffarabad Formation are not recommended unless alkali-free cement, slag cement or pozzolanic ash are being used as the replacement agents. On the other hand, the Margalla Hill Limestone possesses the allowable ASTM/BS standard limits of physical, mechanical, textural and mineralogical properties. The low LAV, AIV, ACV and water absorption of Margalla Hill Limestone corresponds to the fact that it is located further away from the MF zone and also shows a low percentage of the microfractures observed in petrography. Therefore, it is strongly recommended that the Margalla Hill Limestone is the suiTab. construction material for construction in the region. However, CRA from the studied queries are suiTab. for road layers, bridges, pathways, retaining structures, culverts, whereas in cement concrete, only the Margalla Hill Limestone is found suiTab., having no alkali-aggregate reactions (i.e. ASR and ACR).

\section{References}

Adanikin, A., Olutaiwo, A., and Ashamo, A. (2018). Mechanical Strength Determination Of Crushed Stone Aggregate Fraction For Road Pavement Construction (Case Study: Selected Quarries In Western Nigeria).

Ahsan, N., Chaudhry, M. N., Gondal, M. M. I., and Khan, Z. K. (2009). Allai aggregate for rehibilitation and reconstruction of October 8, 2005 earthquake affected allai-banan area, NWFP, Pakistan. Geol. Bull. Punjab Univ, 44, 2009.

Akbulut, H., and Gürer, C. (2007). Use of aggregates produced from marble quarry waste in asphalt pavements. Building and Environment, 42(5), 1921-1930.

Ambraseys, N., and Jackson, D. (2003). A note on early earthquakes in northern India and southern Tibet. Curr. Sci. India 84(4), 570-582.

Armbruster, J., Seeber, L. K., and Jacob, K. B.. (1978). The northwestern termination of the Himalayan mountain front: Active tectonics from micro earthquakes. J. Geophys. Res. 83, 269-282. https://doi.org/10.1029/JB083iB01p00269.

ASTM 127. (2015). Standard Test Method for Relative Density (Specific Gravity), and Absorption of Coarse Aggregates.

ASTM C 131. (2013). Standard Test Method for Resistance to Degradation of Small Size Coarse by Abrasion and Impact in the Los Angeles Machine.

ASTM C 88. (2013). Standard Test Method for Soundness of Aggregates by using Sodium Sulphate or Magnesium Sulphate.

ASTM C-295. (2012). Standard Test Method for Petrographic Examination of Aggregates for Concrete.

Avouac, J. P., Ayoub, F., Leprince, S., Konca, O., and Helmberger, D. (2006). The 2005, Mw 7.6 Kashmir earthquake: Sub-pixel correlation of ASTER images and seismic waveforms analysis. Earth Plant. Sci. Lett. 249(3-4), 514-528.

Baig, M. S., and Lawrence, R. D. (1987). Precambrian to Early Paleozoic orogenesis in the Himalaya. Kashmir J. Geol. 5, 1-22.

Basharat, M., Riaz, M. T., Jan, M. Q., Xu, C., and Riaz, S. (2021). A review of landslides related to the 2005 Kashmir Earthquake: implication and future challenges. Natural Hazards, 1-30.

Bilqees, R, Khan, T., Pirzada, N., and Abbas, S. M., (2012). Industrial applications of Abbottabad limestone: Utilizing its chemical and engineering properties. Journal of Himalayan Earth Sciences, University of Peshawar, 45(1), 91-96.

Bilqees, R., and Shah, M. T. (2007). Industrial Applications of Limestone Deposits of Kohat, NWFP-a research towards the sustainability of the deposit. Pakistan. Journal of Scientific and Industrial Research, 50(5), 293-298.

Bouquety, M. N., Descantes, Y., Barcelo, L., de Larrard, F., and Clavaud, B. (2007). Experimental study of crushed aggregate shape. Construction and Building Materials, 21(4), 865-872.

BS 812-110, 1990. Methods for Determination of Aggregate Crushing Value. BS 812-112: 1990. Methods for Determination of Aggregate Impact Value.

Calkins, J. A., Offield, T. W., Abdullah, S. K. M., and Ali, S. T. (1975). Geology of the southern Himalaya in Hazara, Pakistan, and adjacent areas. US Geological Survey 716C. Washington, DC: USGS. 
De Brito, J., Kurda, R., and Raposeiro da Silva, P. (2018). Can we truly predict the compressive strength of concrete without knowing the properties of aggregates?. Applied Sciences, 8(7), 1095.

Fournari, R., and Ioannou, I. (2019). Correlations between the properties of crushed fine aggregates.

Greco, A. (1989). Tectonic and metamorphism of the western Himalayan Syntaxis area (Azad Kashmir NE Pakistan). Ph.D. dissertation, Geological Institute of the Swiss Federal Institute of Technology and Univ. of Zurich.

Hartley, A. (1974). A review of the geological factors influencing the mechanical properties of road surface aggregates. Q. J. Eng. Geol. 7, 69-100

Jan, N., Bilqees, R., Riaz, M., Noor, S., and Younas, M. (2009). Study of Limestone of Nizampur area for Industrial utilization. Journal of the Chemical Society of Pakistan, 31(1), 16-20.

Kazmi, A. H., and Jan, M. Q. (1997). Geology and tectonics of Pakistan, 557. Karachi, Pakistan: Graphic Publishers.

Koukis, G., Sabatakakis, N., and Spyropoulos, A. (2007) Resistance variation of low-quality aggregates. Bull. Eng. Geol. Environ., 66, 457-466.

Lees, G., and Kennedy, C. K. (1975). Quality, shape and degradation of aggregates. Q. J. Eng. Geol. 8, $28-35$.

Lopez-Buendia, A. M., Climent, V., and Verdu, P. (2006). Lithological Influence of Aggregate in the AlkaliCarbonate Reactio. Cement and Concrete Research, 36(8).

Malahat, F., Naseer, A., and Bilqees, R. (2018). Engineering and Mineralogical Assessment of Coarse Aggregates used in District Mardan. Journal of Himalayan Earth Sciences, 51(1), 34-43.

Munir, H. M., and Baig, M. S. (2006). Paleogene biostratigraphy of Thattapani, Kotli, Azad Kashmir, northwest sub-Himalayas. Pakistan. Jour. Himalayan Earth Sc.39, 39-48.

Mustafa, S., Khan, M. A., Khan, M. R., Sousa, L. M., Hameed, F., Mughal, M. S., and Niaz, A. (2016). Building stone evaluation-A case study of the sub-Himalayas, Muzaffarabad region, Azad Kashmir, Pakistan. Engineering Geology, 209, 56-69.

Naeem, M., Khalid, P., Sanaullah, M., and ud Din, Z. (2014). Physio-mechanical and aggregate properties of limestones from Pakistan. Acta Geodaetica et Geophysica, 49(3), 369-380.

Nakata, T., Tsutsumi, H., Khan, S. H., and Lawrence, R. D. (1991). Vol. 141 of Active faults of Pakistan: Map sheet and inventories. Hiroshima, Japan: Hiroshima Univ.

Neville, A. M. (2000). Properties of Concrete. 4th ed. Pearson Education Asia Pte. Ltd.

Olaleye, B. M. (2012). Establishing relationships between some engineering properties of granitic rock types in selected quarries in South-West, Nigeria. Journal of Emerging Trends in Engineering and Applied Sciences, 3(6), 934-937.

Quiroga, P. N., and Fowler, D.W. (2004). The Effects of Aggregates Characteristics on the Performance of Portland Cement Concrete; Technical Report for International Center for Aggregates Research: Austin, TX, USA.

Riaz, M. T., Basharat, M., Hameed, N., Shafique, M., and Luo, J. (2018). A data-driven approach to landslidesusceptibility mapping in mountainous terrain: case study from the Northwest Himalayas, Pakistan. Natural Hazards Review, 19(4), 05018007.

Seeber, L., and Armbruster, J. (1979). Seismicity of the Hazara Arc in northern Pakistan: Decollement vs. basement faulting. In Geodynamics of Pakistan, edited by A. Farah, and K. A. Dejong, 131-142. Quetta, Pakistan: Geological Survey of Pakistan.

Shah, S. M. I. (2009). Stratigraphy of Pakistan. GSP memoirs 22, 292-293.

Shakoor, A., West, T. R., and Scholer, C. F. (1982). Physical characteristics of some Indiana argillaceous carbonates regarding their freeze-thaw resistance in concrete. Bull. Int. Assoc. Eng. Geol. 19(4), 371-384.

Smith, M. R., and Collis, L. (2001). Aggregates: sand, gravel, and crushed rock aggregates for construction purposes, Sp. Pub, 17, Geological Society, London

Tugrul, A., and Yilmaz, M. (2012). Assessing the Quality of Sandstones for Use as Aggregate in concrete. Mag. Concr. Res. 64, 1067-1078. 